\title{
'Euro-realism' in the 2014 European Parliament elections: \\ the European Conservatives and Reformists (ECR) and the democratic deficit
}

The European Conservatives and Reformists (ECR) emerged as the third largest 'Euro-party' after the 2014 European elections, and are now well-positioned to perform a central role alongside the European People's Party (EPP) and the Progressive Alliance of Socialists and Democrats (S\&D) in the eighth session of the European Parliament (EP). Despite this, relatively little is known about the views that ECR politicians represent, especially their core party ideology of 'Euro-realism'. In this article, it is argued that the development of ECR since 2009 is ultimately rooted in a central desire by its member party politicians to reform the European Union (EU) by addressing its 'democratic deficit' without destroying the wider integration project altogether. More widely, ECR is the most visible vehicle for 'soft' Euroscepticism in the EP, promoting 'governance before policy'.

\section{Acknowledgements:}

The author wishes to thank the anonymous article reviewers for all their helpful comments and suggestions.

Dr Martin Steven is Lecturer in Politics at the University of Lancaster. His research interests lie in the area of political parties and elections - especially British politics and multi-level governance. His work focuses comparatively on the relationship between parties and public policy, and he has published in journals such as 'The Political Quarterly', the 'Australian Journal of Political Science', and also in a monograph for Routledge. 
The 2014 European Parliament (EP) elections were the first to involve party candidates representing the European Conservatives and Reformists (ECR). ECR was established after the previous elections in 2009 by politicians from the United Kingdom (UK), Poland and the Czech Republic who were uncomfortable with the federalist policy of 'ever closer union' (European Union 2009) promoted by the main centre-right group, the European People's Party (EPP). Moreover, ECR performed relatively well in 2014, going on after talks to become the third largest 'Euro-party' behind EPP and the Progressive Alliance of Socialists and Democrats (S\&D) - and ahead of the Alliance of Liberals and Democrats for Europe (ALDE) and the Greens / European Free Alliance (EFA). With 76 Members of the European Parliament (MEPs) in the Brussels and Strasbourg hemispheres, ECR is now a political party with which both EPP and S\&D co-operate extensively in the 2014-19 parliamentary term. ALDE was the 'kingmaker' of the seventh European Parliament (EP7) as the third largest group (see VoteWatch 2011) and ECR can expect to hold the same influence in the eighth Parliament (EP8) given the number of MEPs which now represent it.

Despite this, ECR is a relatively under-researched political movement, certainly compared to other longer established European party families or groupings. Its key political priorities will be outlined in this article, especially those connected to the relatively new concept of 'Eurorealism'. In general, ECR politicians try to highlight constructively problems related to the overall quality of government in the European Union (EU) (see Lijphart [1999]; Rothstein [2011]) and in particular the well-documented 'democratic deficit' (see Follesdal and Hix [2006]; Hobolt and Tilley [2014]; Marquand [1979]) without abandoning European integration altogether. More generally, ECR is the most prominent group representing 'soft' 
Euro-scepticism in the EP (see Brack and Startin [2015]; Taggart and Szczerbiak [2008]; Usherwood and Startin [2013]).

ECR is now made up of 26 parties from 18 different EU member states mostly from northern and central Europe while its larger umbrella group Alliance of European Conservatives and Reformists (AECR) also involves parties from countries outside the EU such as Armenia, Georgia and Turkey. Meanwhile, formal links have been established with partner parties further afield such as the Australian Liberals, the Canadian Conservatives and the Republicans in the United States (US). Many of these parties' natural allies across Europe ought to be EPP and its wider party family, the Christian Democrats (CD) yet that grouping is undermined by the existence of ECR (see Hayward and Wurzel [2012]; Taylor [2007]). While CD politicians such as German Chancellor Angela Merkel and European Commission President Jean-Claude Juncker broadly agree with ECR politicians such as British Prime Minister David Cameron and Polish President Andrej Duda about the benefits of the common market, they disagree fundamentally over the governance role of the EU in these policy areas.

As Table 1 shows, the British Conservatives have the largest number of MEPs in ECR with 20 out of 76 seats and have very much been the driving force of the party since Mr Cameron formally promised to leave EPP in 2005 during his leadership campaign in an attempt to win support from more Euro-sceptic-minded Members of Parliament (MPs) and MEPs (see Lynch and Whitaker [2008]). Law and Justice (PiS) - the governing party of Poland between 2005 and 2007 and once more since October 2015 - has 18 while the Civic Democrats (ODS) from the Czech Republic, led in the past by former President Václav Klaus, now have only 
two MEPs but were central to articulating the concept of 'Euro-realism'. In particular, Czech MEP Jan Zahradil is credited with having written on the subject from 2001 onwards when ODS enjoyed greater electoral success (see Hanley 2007).

\section{Table 1 around here}

Meanwhile, these established parties of government have also been joined by four MEPs from the New Flemish Alliance (N-VA), the biggest party in Belgium, who had previously been aligned to EFA on the basis of its civic nationalist policies for the Flanders region. Other ECR members include the Finns Party (PS), serving in a governing coalition in Helsinki since April 2015, and the Danish People's Party (DF) - along with many individual MEPs from different countries in the EU. Perhaps the most significant addition to ECR since the start of the new parliamentary session came in the form of Alternative for Germany (AfD). By choosing to align its seven ${ }^{1}$ MEPs to ECR, the group overtook ALDE as the third largest parliamentary party for EP8. During EP7, ECR had only 55 MEPs so the results of the 2014 elections and subsequent negotiations surrounding group membership can be considered progress (see McElroy and Benoit 2010).

Figure 1 shows the number of MEPs each group has in EP8 (correct as of March 2016). The two largest European party families continue to hold the most seats - the Christian Democrat vehicle, EPP, has 215 seats while the European Socialists have 190. Nevertheless, it was EPP and S\&D who had their vote squeezed most in 2014 while parties promoting Euro-sceptic positions increased their representation. The Europe for Freedom and Direct Democracy faction (EFDD) now has 45 seats, dominated by the UK Independence Party 
(UKIP) and Italy's Five Star Movement, while the Europe of Nations and Freedom (ENF) group has 38 MEPs, including politicians from the National Front (FN) in France and Party for Freedom (PVV) in The Netherlands. In some EU member states, Euro-sceptic parties performed especially well, often winning the elections in terms of seats and vote share. In France, FN emerged as the largest party with $25 \%$ of the vote, the left-wing SYRIZA won in Greece with $27 \%$ of the vote while UKIP won $28 \%$ of the vote and 24 seats.

Figure 1 around here

\section{Developing 'Euro-realist' policies}

ECR representatives have undertaken a significant amount of policy development since their group was first established by the British Conservatives in 2009 - much of which centres around the intriguing concept of 'Euro-realism'. Yet what exactly do politicians from the now enlarged ECR mean in detail when they say they are 'Euro-realist'? Is this an expedient term quickly thought up as a tactic or does it have more ideological substance? The preamble of the 2009 Prague Declaration refers to the 'urgent need to reform the EU on the basis of Euro-realism, Openness, Accountability and Democracy, in a way that respects the sovereignty of our nations' (ECR 2009). This offers some indication that 'Euro-realism' is primarily concerned with addressing the EU's 'democratic deficit' above all else - in particular, the need to protect the sovereignty of national parliaments to make law from the pressures of 'ever closer union'. According to ECR (2014), 'the Euro-realism concept distinguishes the ECR's agenda from the other political groups. We believe in a new direction for the EU, which does not destroy the organisation or undermine cooperation'. When paying tribute to his predecessor as ECR leader, Martin Callanan, the new leader Syed 
Kamall stated: 'Martin has been a strong supporter of European reform and Euro-realism, and his hard work is a major part of the reason why the ECR is now growing and attracting new member parties' (BBC News 2014c).

After the 2014 elections, ECR augmented the Prague Declaration with the Reykjavik Declaration - and it is striking that seven out of the eight principles outlined now involve issues surrounding the quality of democracy in Europe. These include the importance of EU member states retaining their independence, the need for power to be exercised at the lowest level possible, the hope that individuals can be free from state interference, protecting the rule of law and 'cherishing' the role of civic associations in society (ECR, 2015a). Only one - principle eight - refers to the need for the EU to prioritise trade, competition and commerce. A further investigation into ECR policy literature shows how the values of 'reform' and 'democratic accountability' constitute the main driving ideas behind 'Euro-realism' (ECR 2015b). In one party article, ECR representatives also articulate the importance for 'thinking governance before policy' (ECR 2015c): 'a governance structure, like the European Union, must be critiqued against principles apart from its ability to deliver policy'. It may also be noted that, according to VoteWatch (2014), ECR maintained a relatively strong 'internal cohesion' during European parliamentary term 2009-14, particularly when it came to policy areas such as constitutional matters.

However, crucially, unlike the ENF and EFDD representatives, politicians from many ECR parties would regard themselves as 'pro-European'. In the case of the New Flemish Alliance, for example, this is linked to what the party perceives as the advantages brought to the Flanders region by European investment - on its website under 'frequently asked 
questions', it states that N-VA is 'without any doubt...a pro-Europe party' (N-VA [2015]; see also Leruth [2014]). While AfD politicians do not support economic and monetary union and regard the Euro as a failed currency (Alternative for Germany 2014), they 'bristle' at being called 'Euro-sceptic' (BBC News 2014b). With regard to ODS, Hanley (2014) argues that its politicians display 'scepticism without Euro-scepticism' in the Czech Republic. Finally, even PiS' opposition to what it regards as the EU's equalities agenda and the implementation of the European Charter of Fundamental Rights does not lead it as Poland's governing party to support withdrawal from the EU altogether - rather, its politicians prefer to use rhetoric to argue that Europe should serve Poland, not vice versa, even arguing that adopting the Euro could theoretically benefit the national interest (see Szczerbiak [2014; 2012]).

In this regard, ECR representatives therefore stand apart both from EPP politicians who regard European integration as being inseparable from the European common market and also from 'hard' Eurosceptic politicians who wish to see an end to the EU altogether - see Table 2 . This analysis confirms the inherent usefulness of the Sussex School's 'soft' and 'hard' distinctions of party-based Euro-scepticism - an approach which emphasises that the policy platforms of ECR parties effectively constitute a form of 'soft' Euro-scepticism - as opposed to the 'hard' Euro-scepticism which is embodied by parties such as UKIP, as well as FN or PVV (see Taggart and Szczerbiak 2008). Related definitions include identifying types of moderate 'policy' Euro-scepticism - for example, supporting European integration but opposing the Euro - as well as more populist manifestations of 'national-interest' Euroscepticism (see also Topaloff 2012). The successful emergence of ECR since 2009 is ultimately rooted in a desire by its representatives to reform the EU to improve its governance - ECR is now therefore the most visible organisation associated with 'soft' Euro- 
scepticism represented in the EP, promoting 'governance before policy' in the hope that it can democratise the internal workings of the EU (ECR 2015c).

\section{Table 2 around here}

For example, in the months preceding the referendum on 23 June 2016 asking voters whether or not Britain should leave or remain in the EU, Prime Minister David Cameron spent a considerable amount of time renegotiating key elements related to how the EU functions. In November 2015, he set out his four key objectives in a letter to the President of the European Council, Donald Tusk. Two of these four aims were explicitly related to 'quality of governance' issues. First, Mr Cameron wanted an assurance that the UK could opt out of the core European principle of 'ever closer union', protecting in the process its sovereignty. Second, he also pressed for greater clarity in 'economic governance', ensuring that member states like the UK which were not members of the Eurozone would not be regarded as peripheral to any future financial decision-making that affects all EU-28. Indeed, even a third demand concerning 'competiveness' alluded to the wider structural framework and regulations of the single market (Cameron 2015).

Identifying accurately the main elements of 'Euro-realism' is especially relevant given the way radical right parties like FN and PVV have now taken up the Euro-sceptic cause and started to be critical of the open borders created by the EU. Political scientists have long debated the type of recognisable criteria that apply to a 'populist' political party or a 'farright' one (see Mudde 2007). On the whole, the major ECR member parties can be clearly distinguished from many of the representatives in EFDD as well as the more radical ENF 
MEPs - nevertheless, this remains a problematic aspect of the eighth EP for the British Conservatives as the only long-established Western European party of government in ECR (see Bale et al 2010).

While both Central European parties, Poland's Law and Justice and the Czech Civic Democrats, can be considered on the whole 'mainstream' right of centre organisations, their political activities are not entirely without controversy. PiS promotes a socially conservative position on issues related to human sexuality and family values (see Szczerbiak 2014) as well as a traditionalist form of Polish nationalism while ODS became mired in a corruption scandal surrounding the financial activities of former Czech President Václav Klaus and the former Mayor of Prague, Pavel Bém - suffering electorally as a consequence (see Hanley 2014). In the Nordic countries, both the Finns Party and the Danish People's Party can at the very least be regarded as 'populist' due to their often hostile stances towards immigration and multi-culturalism (see Meret [2010; Niemi [2013]). While AfD from Germany and the Belgian N-VA could not always be categorised as such, they have also at times been perceived to make negative contributions to these types of social cohesion issues - in particular, AfD has moved increasingly in that policy direction (see BBC News [2014a]; Lees [2015]; Table 3).

Table 3 around here

Yet collectively at least, ECR can be said to be the main standard holders for 'soft' Euroscepticism in the new EP, advocating a small state political economy model which encourages sovereign European countries to freely trade with one another (see Esping- 
Andersen 1990). This model can be contrasted with the corporatist European Social Model (ESM) associated with the Christian Democrats in countries such as Germany, The Netherlands, Austria and Belgium and more widely the EU itself - CD politicians promote a partnership between business, trade unions and government, and are relaxed about the overall size of the state. For example, a few months after the 2014 elections, British Prime Minister David Cameron met German Chancellor Angela Merkel, Dutch Prime Minister Mark Rutte $^{2}$, and Fredrik Reinfeldt, the then Swedish Prime Minister, to discuss the future direction of the type of free market capitalist policies that they all broadly support. While they were in agreement over the need to promote greater levels of fiscal prudence across the 28 EU member states, they disagreed over whether 'ever closer union' was the problem or the solution to the ongoing financial crisis (BBC News 2014d). For ECR politicians, many of whom come from countries such as Britain and Poland where there is no Christian Democratic tradition ${ }^{3}$, the ESM has itself become a problematic part of the wider purpose of European governance since the Treaty of Maastricht was signed in 1992.

\section{Identifying 'Euro-realist' voters}

The key aim of this article is to understand the still emerging political values of ECR more clearly - in order to do this, it is important to examine voting behaviour as well as policy positions. Moderate 'Euro-realist' concerns appear to be reflected in the political views of voters who support ECR parties - especially the British Conservatives. Conservative Party voters are generally on the 'Euro-sceptic' wing of the political spectrum and the policies of a party like UKIP are attractive to many of them. Yet equally, that is not quite the same as definitely wanting to leave the EU altogether. As a consequence of their parties' increased representation, the level of detail in survey data surrounding the political attitudes of 'Euro- 
sceptic' voters has also improved - and this type of research is also helpful when trying to understand the policy development of ECR. Party politics across many European countries has become more multi-polar - including in the UK where ECR has its main voter base in the Conservative Party. The Conservatives also provide the wider ECR / AECR network with the bulk of its institutional leadership and support in Brussels, including its chair in the Parliament Syed Kamall MEP, chief executive Richard Milsom and secretary general Daniel Hannan MEP. An analysis of recent data taken from the 2013 British Social Attitudes Survey shows how it is possible to quantifiably distinguish Conservative supporters from voters of other parties on many political issues related to Europe - especially UKIP.

In an attempt to advance democratic reforms in the EU, the UK Conservative Government legislated for an 'in-out' referendum in June 2016. This process also allowed the Conservatives to offer British voters an opportunity to democratically endorse EU membership for the first time since 1975. In response to the question: 'How would you vote in a referendum to decide whether Britain does or does not remain a member of the EU?', Table 4 shows that Conservative voters are essentially split over the issue of whether Britain ought to leave the EU altogether, with $34 \%$ wishing to remain, while $82 \%$ of UKIP voters are very much in favour of leaving. Meanwhile, both Labour and Liberal Democrat voters display greater enthusiasm for remaining in the EU than either Conservative or UKIP identifiers.

Table 4 around here 
In order to make a more controlled estimation for identifying British voters' political attitudes towards Europe, the recent data taken from the British Social Attitudes Survey were analysed further. Multinomial logistic regression analysis was used as an appropriate model for comparing party support between Conservatives and UKIP in particular, controlling for socio-economic characteristics and political attitudes related to European integration. ${ }^{4}$ In order to make the analysis clearer, the focus is only on the four main UK political parties, with the Conservative Party compared to the other three: Labour, the Liberal Democrats and UKIP. Table 5 includes the results of analysing the differences in respondents' voting preferences based on their attitudes towards issues related to Europe as well as controlling for other socio-economic characteristics.

\section{Table 5 around here}

The results show that characteristics such as age, gender and education, and attitudes such as appreciating the benefits of EU membership, are all significant variables for distinguishing between the party identification of respondents. As respondents get older, they prefer to vote Conservative rather than Labour or Liberal Democrat. With regard to gender, it can be noted fewer women voters appear to identify with UKIP than with the Conservatives. Meanwhile, respondents with post-school qualifications tend to vote Conservative rather than Labour compared to respondents with no-post school qualifications, and the same applies if Conservatives are compared with Liberal Democrats. In terms of attitudes towards the EU, those respondents who recognise the benefits of the UK being in the EU are more likely to vote Labour than Conservative, with the same type of relationship apparent 
between the variables for predicting a vote for the Liberal Democrats over the Conservatives.

Importantly, when party identification for the Conservatives is compared with party identification for UKIP, those who see the benefits of EU membership for Britain are much more likely to vote Conservative than UKIP. The more the subject is optimistic about the role of the UK in the EU, the more he or she will be prone to support the Conservatives over UKIP. ${ }^{5}$ While Labour and Liberal Democrat voters can be considered more enthusiastic about the EU than Conservatives, Conservative voters are still much more positive than UKIP supporters - on this basis, Conservative voters can be placed in the middle of the spectrum of British voter attitudes towards Europe. With regard to acknowledging the benefits of immigration from other EU member states, Labour identifiers appear to be more positive than Conservative voters, although in turn, Conservatives are happier to recognise the wider benefits of free trade than Labour supporters. 'Euro-realist' British Conservative voters, then, seem to echo the wider sentiments of ECR party leaders, as well as many Europeans, according to Eurobarometer data (European Commission 2007; 2011) - broad support for the European integration process but not without any criticisms or reservations.

The growth and formal development enjoyed by ECR parties from 2009 to 2014 can be in part connected to the wider political fallout from the Eurozone crisis and the subsequent structural reforms initiated by member state governments on the recommendation of the European Commission, the European Central Bank and the International Monetary Fund. Support for European integration remains relatively healthy across EU-28 but structural problems associated with the democratic deficit in Brussels have also begun to be 
highlighted more and more. ECR politicians are able to pursue an 'inter-governmental' (Hoffman 1966) alternative to the 'integrationist' agenda so prevalent amongst EPP politicians whilst also simultaneously remaining distinct from more populist and 'hard' forms of Euro-scepticism increasingly prevalent in public opinion.

\section{Conclusion}

In 2006, at the Conservative Party conference, and before he became UK Prime Minister, David Cameron stated: 'We need to stop banging on about Europe' (BBC News 2006). Mr Cameron's aim was to suggest that adopting an extreme approach to European integration was not constructive, and certainly not the way for his party to win back power. The comment also simultaneously reveals a divide between the British Conservatives and enthusiasts for 'ever closer union' such as the German Christian Democrats who regard European affairs as central to all aspects of public policy. Equally, for 'hard' Euro-sceptics such as UKIP, European integration is not a matter for realistic reform - it is an entirely wrong policy to be abandoned as soon as is possible. In leaving EPP, Mr Cameron has been able to make a symbolically 'Euro-sceptic' gesture while simultaneously remaining distinct from the more radical politics of UKIP and its parliamentary group, EFDD (see Bale 2006).

Ultimately, 'Euro-realism' articulates a wider desire reflected in European public opinion for reforming the EU without destroying completely the wider European integration process. Europe's dominant conservative strain may be Christian Democracy, directly mixing economic policies with social policies, but 'Euro-realist' ECR politicians would argue that the roots of Europe's present crisis are ultimately a consequence of placing those types of 
policies before addressing problems connected with the wider quality of EU governance and perceptions of a 'democratic deficit'. 


\section{References}

ALTERNATIVE FOR GERMANY. 2014. English summary of the party programme. Available at: http://www.alternativefuer.de/wp-content/uploads/2014/04/AfD-Manifesto-for-Europesummary.pdf.

BALE, TIM, SEAN HANLEY and ALEKS SZCZERBIAK. 2010. 'May contain nuts?' The reality behind the rhetoric surrounding the British Conservatives' new group in the European Parliament. The Political Quarterly 81 (1): 85-98.

BALE, TIM (2006) Between a soft and a hard place: the Conservative Party, valence politics and the need for a new 'Euro-realism'. Parliamentary Affairs 59 (3): 385-400.

BBC NEWS. 2006. Cameron places focus on optimism. Available at: http://news.bbc.co.uk/1/hi/uk_politics/5396358.stm, 1 October.

BBC NEWS. 2014a. Anti-Islam demonstrations in Germany 'getting bigger'. Available at: http://www.bbc.co.uk/news/world-europe-30489799, 16 December.

BBC NEWS. 2014b. Germany's Alternative für Deutschland shakes up politics. Available at: http://www.bbc.co.uk/news/world-europe-29010588, 2 September.

BBC NEWS. 2014c. Anti-euro party joins conservative group of MEPs. Available at: http://www.bbc.co.uk/news/uk-politics-27822203, 12 June. 
BBC NEWS. 2014d. Cameron hails all-party support against Juncker bid. Available at: http://www.bbc.co.uk/news/uk-politics-27757991, 10 June.

BRACK, NATHALIE AND STARTIN, NICHOLAS. 2015. Euro-scepticism, from the margins to the mainstream. International Political Science Review 36 (3): 239-49.

CAMERON, DAVID. 2015. A New Settlement for the United Kingdom in a Reformed European Union. Letter to the President of the European Council, 10 November. Available at: https://www.gov.uk/government/uploads/system/uploads/attachment_data/file/475679/D onald_Tusk_letter.pdf.

DALTON, RUSSELL, DAVID FARRELL AND IAN MCALLISTER. 2011. Political Parties and Democratic Linkage: How Parties Organize Democracy. Oxford: Oxford University Press.

ESPING-ANDERSEN, GØSTA. 1990. The Three Worlds of Welfare Capitalism. Cambridge: Polity Press.

EUROPEAN COMMISSION. 2011. Eurobarometer 75. Available at:

http://ec.europa.eu/public_opinion/archives/eb/eb75/eb75_cri_en.pdf.

EUROPEAN COMMISSION. 2007. Eurobarometer 67. Available at: http://ec.europa.eu/public_opinion/archives/eb/eb67/eb67_en.pdf. 
EUROPEAN CONSERVATIVES AND REFORMISTS. 2015a. The Reykjavik Declaration. Available at: http://www.aecr.eu/principles/, accessed 11 June 2015.

EUROPEAN CONSERVATIVES AND REFORMISTS. 2015b. AECR. Available at: http://www.aecr.eu/, accessed 11 June 2015.

EUROPEAN CONSERVATIVES AND REFORMISTS. 2015c. Thinking governance before policy. Available at: http://www.aecr.eu/thinking-governance-before-policy/, accessed 11 June 2015.

EUROPEAN CONSERVATIVES AND REFORMISTS. 2014. Euro-realism. Available at: http://ecrgroup.eu/about-us/the-ecr-in-the-european-parliament, accessed 11 June 2015. EUROPEAN CONSERVATIVES AND REFORMISTS. 2009. The Prague Declaration. Available at: http://ecrgroup.eu/policy/the-prague-declaration, accessed 11 June 2015.

EUROPEAN UNION. 2009. Treaty of Lisbon: Taking Europe into the Twenty First Century. Brussels: Europa. Available at: http://eur-lex.europa.eu/legalcontent/EN/TXT/PDF/?uri=OJ:C:2007:306:FULL\&from=EN.

FOLLESDAL, ANDREAS AND SIMON HIX. 2006. Why there is a democratic deficit in the EU: a response to Majone and Moravcsik. Journal of Common Market Studies 44 (3): 533-62. 
HANLEY, SEAN. 2014. Czech Republic: scepticism without Euro-scepticism. Dr Sean's Diary. Available at: http://drseansdiary.wordpress.com/2014/03/22/czech-republic-scepticismwithout-euro-scepticism/\#more-2482, 22 March.

HANLEY, SEAN. 2007. Czech Transformation and Right-Wing Politics, 1989-2006. London: Routledge.

HAYWARD, JACK AND RUDIGER WURZEL (eds). 2012. European Disunion: Between Sovereignty and Solidarity. London: Palgrave Macmillan.

HOBOLT, SARA AND JAMES TILLEY. 2014. Blaming Europe: Responsibility without Accountability in the European Union. Oxford: Oxford University Press.

HOFFMAN, STANLEY. 1966. Obstinate or obsolete? The fate of the nation state and the case of Western Europe. Daedalus 95 (3): 862-915.

LEES, CHARLES. 2015. The AfD: what kind of alternative for Germany?' Paper presented at the $65^{\text {th }}$ Political Studies Association conference, Sheffield, 30 March -1 April.

LERUTH, BENJAMIN. 2014. The New Flemish Alliance's decision to join the ECR group says more about Belgian politics than it does about their attitude toward the EU. LSE EUROPP blog, available at: http://blogs.Ise.ac.uk/europpblog/2014/06/23/the-new-flemish-alliancesdecision-to-join-the-ecr-group-says-more-about-belgian-politics-than-it-does-about-theirattitude-toward-the-eu/, 23 June. 
LIJPHART, AREND. 1999. Patterns of Democracy: Government Forms and Performance in Thirty Six Countries. New Haven: Yale University Press.

LYNCH, PHILIP AND WHITAKER, RICHARD. 2008. A loveless marriage: the Conservatives and the European People's Party. Parliamentary Affairs 61 (1); 31-51.

MCELROY, GAIL AND KENNETH BENOIT. 2010. Party policy and group affiliation in the European parliament. British Journal of Political Science 40 (2): 377-98.

MAIR, PETER (ed). 1990. The West European Party System. Oxford: Oxford University Press.

MARQUAND, DAVID. 1979. Parliament for Europe. London: Cape.

MERET, SUSI. 2010. The Danish People's Party, the Italian Northern League and the Austrian Freedom Party in a comparative perspective: party ideology and electoral support. SPIRIT PhD Series, No. 25, Aalborg University, available at:

http://vbn.aau.dk/files/20049801/spirit_phd_series_25.pdf.

MUDDE, CAS. 2007. Populist Radical Right Parties in Europe. Cambridge: Cambridge University Press.

NIEMI, MARI. 2013. The True Finns: identity, politics and populist leadership on the threshold of the party's electoral triumph. Javnost - The Public 20: 3, 77-92. 
ROTHSTEIN BO. 2011. The Quality of Government: Corruption, Social Trust and Inequality in International Perspective. Chicago: Chicago University Press.

SZCZERBIAK, ALEKS. 2014. Law and Justice are likely to come out ahead in the European Parliament elections in Poland. LSE EUROPP blog, available at: http://blogs.Ise.ac.uk/europpblog/2014/01/30/law-and-justice-are-likely-to-come-outahead-in-the-european-parliament-elections-in-poland/, 30 January.

SZCZERBIAK, ALEKS. 2012. Poland within the European Union: New Awkward Partner or New Heart of Europe? London: Routledge.

TAGGART, PAUL AND ALEKS SZCZERBIAK (eds). 2008. Opposing Europe: The Comparative Party Politics of Euro-scepticism. Oxford: Oxford University Press.

TAYLOR, PAUL 2007. The End of European Integration: Anti-Europeanism Examined. London: UACES / Routledge.

TOPALOFF, LIUBOMIR. 2012. Political Parties and Euro-scepticism. London: Palgrave Macmillan.

USHERWOOD, SIMON AND STARTIN, NICHOLAS. 2013. Euro-scepticism as a persistent phenomenon. Journal of Common Market Studies 51 (1): 1-16. 
VOTEWATCH. 2014. Cohesion of (trans-national) political groups in the European parliament. Available at: http://term7.votewatch.eu/en/political-group-cohesion.html, accessed 11 June 2015.

VOTEWATCH. 2011. Voting in the 2009-2014 European Parliament: How Do MEPs Vote after Lisbon? (Third Report). Available at: http://www.votewatch.eu/blog/wpcontent/uploads/2011/01/votewatch_report_voting_behavior_26_january_beta.pdf. 


\section{Appendix}

Table 1: ECR member state parties, European Parliamentary Term 2014-2019

\begin{tabular}{|c|c|c|}
\hline Political party & Member state & MEPs \\
\hline Conservatives & United Kingdom & 20 \\
\hline Law and Justice & Poland & 18 \\
\hline Alliance for Progress and Renewal & Germany & 5 \\
\hline New Flemish Alliance & Belgium & 4 \\
\hline Danish People's Party & Denmark & 4 \\
\hline *Alternative for Germany & Germany & 2 \\
\hline Civic Democrats & Czech Republic & 2 \\
\hline Finns Party & Finland & 2 \\
\hline Conservatives and Reformists & Italy & 2 \\
\hline Bulgaria Without Censorship & Bulgaria & 1 \\
\hline Bulgarian National Movement & Bulgaria & 1 \\
\hline Croatian Party of Rights & Croatia & 1 \\
\hline Independent & Cyprus & 1 \\
\hline Family Party & Germany & 1 \\
\hline Notis Marias & Greece & 1 \\
\hline Brian Crowley & Ireland & 1 \\
\hline National Alliance & Latvia & 1 \\
\hline Electoral Action of Poles & Lithuania & 1 \\
\hline Christian Union & Netherlands & 1 \\
\hline Reformed Political Party & Netherlands & 1 \\
\hline M10 & Romania & 1 \\
\hline Right Wing of the Republic & Poland & 1 \\
\hline Freedom and Solidarity & Slovakia & 1 \\
\hline New Majority & Slovakia & 1 \\
\hline Ordinary People & Slovakia & 1 \\
\hline Ulster Unionists & United Kingdom & 1 \\
\hline
\end{tabular}

*Expelled from group, March 2016 
Table 2: Conservative, centre-right and populist 'Euro-party' policy positions

\begin{tabular}{ccccc}
\hline Party & $\begin{array}{c}\text { Ever closer } \\
\text { union }\end{array}$ & $\begin{array}{c}\text { Democratic } \\
\text { deficit }\end{array}$ & $\begin{array}{c}\text { European } \\
\text { common market }\end{array}$ & $\begin{array}{c}\text { European free } \\
\text { movement of } \\
\text { people }\end{array}$ \\
\hline EPP & In favour & Low priority & In favour & In favour \\
\hline ECR & Against & High priority & In favour & Mixed \\
\hline EFDD & Against & Irrelevant & Against & Against \\
\hline
\end{tabular}


Table 3: ECR member parties and key group policy aims

\begin{tabular}{lll}
\hline Free countries & Free markets & Free people \\
& & \\
\hline Conservatives & Conservatives & Conservatives \\
\hline ALFA & ALFA & ALFA \\
\hline N-VA & N-VA & \\
\hline ODS & ODS & \\
\hline PiS & & \\
\hline DF & & \\
\hline PS & & \\
\end{tabular}


Table 4: How would you vote in a referendum on EU membership (\%)?

\begin{tabular}{cccc}
\hline & Remain in the EU & Leave the EU & Cannot choose \\
\hline Conservative & 34 & 43 & 22 \\
\hline Labour & 49 & 28 & 22 \\
\hline Liberal Democrat & 59 & 24 & 18 \\
\hline UKIP & 10 & 82 & 8 \\
\hline
\end{tabular}

Source: British Social Attitudes Survey 2013 
Table 5: Predicting British political party identification

\begin{tabular}{lccc}
\hline & \multicolumn{3}{c}{ (Parameter estimates and standard errors) } \\
\cline { 2 - 4 } Socio-economic & Lab vs. Con & Lib Dem vs. Con & UKIP vs. Con \\
characteristics & & & \\
Age & $-0.28(0.06)^{* * *}$ & $-0.19(0.11)^{*}$ & $-0.42(0.11)$ \\
Gender & $-0.03(0.19)$ & $0.28(0.34)$ & $-0.87(0.34)^{* * *}$ \\
Marital status & $0.36(0.20)^{*}$ & $0.46(0.34)$ & $-0.25(0.36)$ \\
Education & $0.71(0.22)^{* * *}$ & $0.59(0.39)^{*}$ & $0.16(0.36)$ \\
Occupation & $0.34(0.24)$ & $-0.43(0.46)$ & $0.60(0.43)$ \\
& & & \\
Political attitudes & $0.34(0.30)$ & $-0.97(0.40)^{* *}$ & $-0.16(0.55)$ \\
Feeling European & $0.41(0.11)^{* * *}$ & $0.26(0.18)^{*}$ & $-0.91(0.21)^{* * *}$ \\
Benefits of EU & & & \\
membership & $0.17(0.08)^{* *}$ & $0.14(0.14)$ & $0.85(0.14)$ \\
Benefits of EU & & & $-0.25(0.23)$ \\
immigration & $-0.29(0.13)^{* *}$ & $0.49(0.24)^{* *}$ & \\
Benefits of free trade & & -0.37 & 3.53 \\
& -0.58 & & \\
\hline Constant & 0.24 & & \\
Nagelkerke R-Sq & $(817)$ & & \\
(N) & & & \\
\hline
\end{tabular}

Notes: $*, * *, * * *$ statistically significant at $\mathrm{p}<.1, \mathrm{p}<.05, \mathrm{p}<.01$ respectively. Multinomial logistic regression presenting equations on predicting differences between respondents' party identification. The dependent variable on party identification includes five categories, with those of particular interest presented in the table above; independent variables are all coded 1 or 0 , or on a continuous scale.

Source: As Table 4 
Figure 1: Number of MEPs by party in the eighth European Parliament (2014-19)

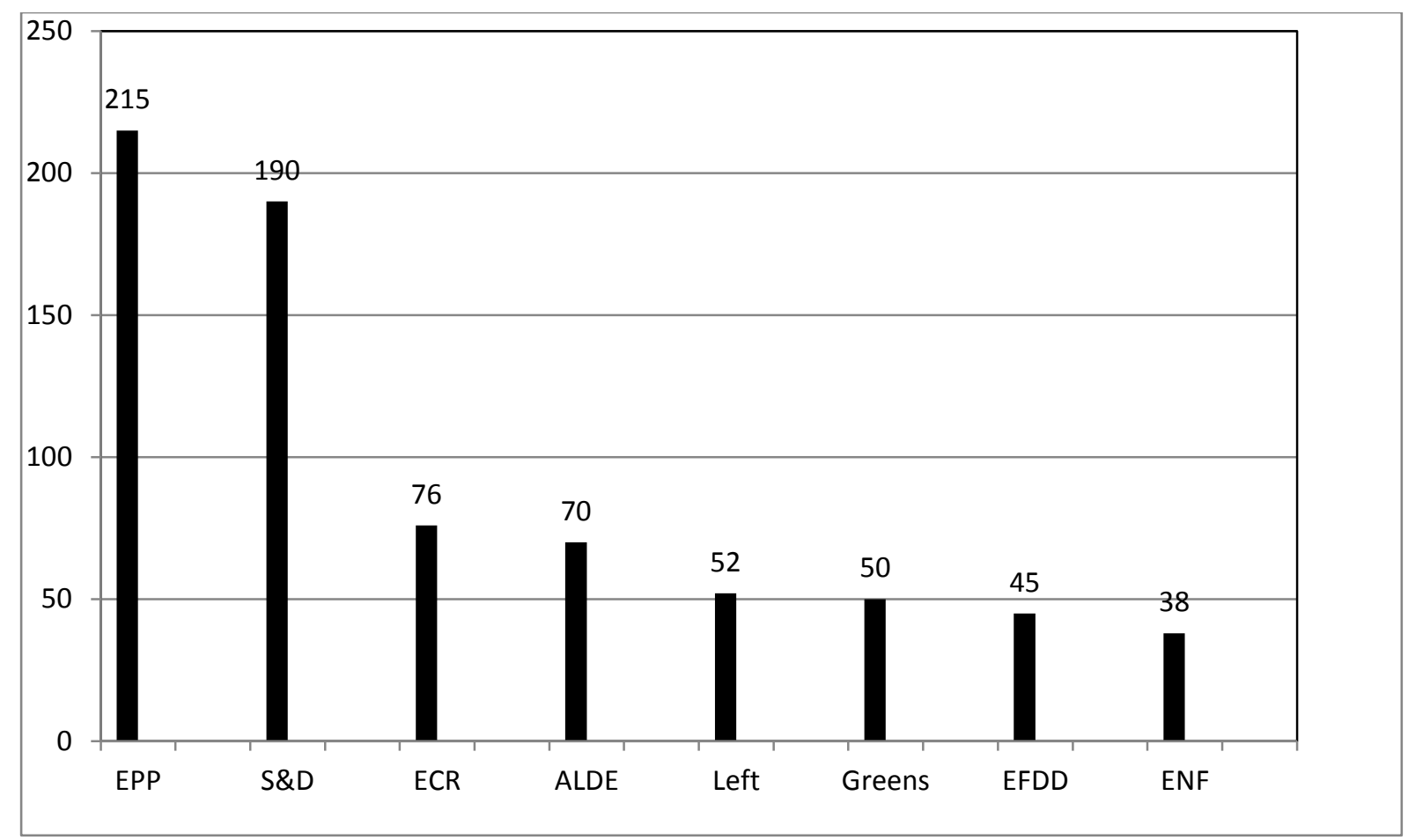


1. In July 2015, AfD split, with former leader Bernd Lucke establishing a new party, Alliance for Progress and Renewal (ALFA). However, the five MEPs who left, including Mr Lucke, all remain in ECR.

2. It may be noted that Mr Rutte is the leader of the People's Party for Freedom and Democracy (VVD) in The Netherlands which is aligned to ALDE, not EPP. Nevertheless, the acrimonious nature of the UK Conservatives leaving EPP is substantively different from VVD politicians choosing not to be in the same group as the Dutch Christian Democrats (CDA).

3. For more on the ideological distinction between 'conservative' and 'Christian Democrat', see Dalton et al (2011) and Mair (1990).

4. The explanatory variable has more than two categories to be analysed; explanatory variables are both categorical and on a continuous scale.

5. If a subject were to increase his or her score on the benefits of the EU by one point, the multinomial log odds of him or her preferring UKIP to Conservatives would be expected to decrease by 0.91 units while holding all other variables in the model constant. 